Carroll, William K. and Jean Philippe Sapinski. 2011. "Corporate Elites and Intercorporate Networks." Pp. 180-95 in The SAGE Handbook of Social Network Analysis, edited by Peter J. Carrington and John Scott. London: SAGE Publications.

\title{
Corporate Elites and Intercorporate Networks
}

\author{
W. K. Carroll and J.P. Sapinski
}

\section{Introduction}

Although systematic network analyses mapping the social organization of business power date only from the 1970s, scholars have explored the relations that link corporations and their directors into corporate elites and intercorporate networks for over a century. Otto Jeidels's (1905) study of the relationship of German banks to industry, the first noteworthy investigation of this kind, discovered 1,350 interlocking directorates between the six biggest banks and industry. He related the interlock network to "a new phase in German industrial development caused by concentration and launched by the economic crisis of 1900" (Fennema and Schijf, 1978: 298). This chapter reviews the empirical work that followed from Jeidels, with an emphasis upon the period since the 1970s, when social scientists turned to network analysis as the primary means of representing the structure of elite and intercorporate relations.

First, some terminology. Networks linking corporations and their directors are known as "twomode" or "affiliation" networks (see Borgatti, this volume): they contain two kinds of nodes (directors and corporations), with lines running only between one kind and the other. When an individual sits on two corporate boards concurrently, (s)he is said to hold interlocking directorships with the two companies, which also means that the directorates of the companies interlock, tying them together at the level of governance. For individuals, interlocking directorships enable participation in governance 
of multiple firms, thereby enhancing contacts, influence, and prestige. For firms, interlocking directorates put boards in contact, and may enable coordination of business strategies within an interlocked group. There is a duality in networks of directors and the corporate boards on which they sit (Breiger, 1974), which is reflected in this chapter's title. These affiliation networks simultaneously draw together persons and large corporations, and they can be fruitfully analyzed on either level. As such, the study of these networks is relevant to a number of issues, including economic organization and the structure of capitalist classes (Scott, 1985: 2).

Large corporations are governed by boards of directors, elected at annual meetings of shareholders on the basis of one share, one vote - a system that favours owners of large blocks of shares - whether the shares are held by persons, other corporations, or institutional investors. Each corporate directorate is typically made up of both internal executives (insiders) and outside directors who do not hold executive positions in the firm. Individuals who hold interlocking directorships in large corporations include those with only outside directorships as well as executives of firms with which they are principally affiliated. In either case, "their directorships spread throughout the economy, and they form a corporate or business elite" (Scott, 1991: 182). An elite, however, is more than a set of advantaged individuals; it refers to "those who occupy the most powerful positions in structures of domination" (Scott, 2008: 33). As hierarchical organizations controlled by major shareholders, top executives, or some combination of both, large corporations are structures of domination par excellence. However, a corporate elite is different from a capitalist class, though the former, in its coordinated agency as an "organized minority" (Brownlee, 2005), may be the "leading edge" of the latter. “An economic elite,” says Scott (2008: 37), “is an inter-organizational group of people who hold positions of dominance in business organizations and who may, under certain circumstances, have certain additional powers available to them." Interlocks figure heavily in creating or reflecting these circumstances. Just as interlocking directorships furnish the basis for a more or less cohesive corporate 
elite, interlocking directorates create relations between companies that add up to an intercorporate network.

Of course, it was not always so. Although elites and dominant classes have existed for millennia, corporate elites and intercorporate networks are creatures of advanced capitalism, going back only about a century or so, to the merger movements of the late nineteenth and early twentieth centuries that created, in the core regions of world capitalism, today's large corporations or their predecessors (Stanworth and Giddens, 1975). Jeidels's (1905) pioneering work emphasized the formation of networks of interlocking directorships between German industry and banks that accompanied this new phase of concentration. Rudolf Hilferding's (1981 [1910]) conception of finance capital as the symbiotic relation between money capital and industrial capital offered a theorization of the new power structure. On the one hand, banks needed an outlet to invest their accumulated capital; on the other, industry's scale of production had reached the point that only the largest banks could provide sufficient capital. Integration and coordination of the system was managed by a small circle of finance capitalists whose corporate affiliations linked banks with top industrial corporations. In the United States, the first reference to interlocking directorates comes from the Pujo Committee, a congressional investigation set up in 1912 to address the growing concerns about this system of bank power undermining market competition (Scott, 1997: 106). Another investigation directed by Paul Sweezy in the 1930s examined the bases of ownership of corporations, their interlocking directorates, and the control exerted by large banks on them. Sweezy was the first to delineate in the U.S. economy several interest groups among the 200 largest corporations and the 50 largest banks (Sweezy, 1953: 166-67).

Concerns with the concentration of power found another expression in C. Wright Mills's (1956) theory of the power elite, as well as in the work of the Canadian sociologist John Porter $(1955,1957)$. Both Mills and Porter invoked social networks more as metaphor than as full-fledged research method. 
Mills argued that corporate interlocking creates, among leading corporate executives and the very rich, an elite that is autonomous from specific property interests. These interlockers, along with shareholders whose investments span many sectors, come to embrace classwide interests that transcend specific property interests (Mills 1956: 123). Interlocks offer to these elites a potential for exchanging views, consolidating the corporate world by unifying the outlook and policy of the propertied class (ibid.). Porter shared Mills's concerns about the threat to democracy posed by the concentration of economic power. His study of interlocks in Canada revealed a strong relationship between banks and industrial corporations, as bankers sat on industrial boards and vice versa (Porter 1956: 211). The classic work of

G. William Domhoff (1967) also treated social networks more as metaphor than method. His interest in power structures led him to stress the role of elite networks in creating unity. Domhoff's key contribution was to extend the analysis of interlocking to organizations that are part of the policyplanning process, such as business associations, policy forums, and think tanks (see Bond and Harrigan, this volume).

\section{Power structure research and the turn to network analysis}

The groundwork having been laid in the 1950s and 1960s, "power structure research" came into its own in the 1970s (Domhoff, 1980), as researchers in the United States articulated an alternative to pluralist readings of economic and political power. The debate revolved mainly around the question of the unity and cohesiveness of the corporate elite. Against the pluralist position that market competition precludes elite unity, structuralist researchers used network analysis to reveal elite cohesion, and the capacity for political action.

At the level of individual directors, common participation in civic and political organizations (social clubs, foundations, universities, business associations and forums) as well as on corporate boards was found to foster social cohesion (Domhoff, 1974; Koenig and Gogel, 1981; Moore, 1979). 
Power structure research showed how individual directors connect, through the many venues where they meet, exchange ideas, and discuss economic as well as political issues. Useem $(1978,1984)$ identified, as the "dominant segment" of the capitalist class, an "inner circle" of corporate interlockers, directors of multiple firms who possess greater wealth than single-firm directors, have more connections to financial institutions, and show a higher degree of social cohesion and of political influence (Useem, 1978). Elite cohesion, moreover, was shown to have biographical depth. Studies in the United Kingdom indicated that most corporate directors share a similar background of privilege and inherited wealth, and that elites' educational and social backgrounds had become increasingly homogeneous in the twentieth century (Stanworth and Giddens, 1975; Whitley, 1974). Domhoff (1974) drew from experimental research on group dynamics to show that proximity and face-to-face communication enhance group cohesion, which in turn facilitates consensus formation in problem solving. For power structure researchers, the extensive network connecting corporate directors, layered upon personal networks that reach back to common educational and social backgrounds, promoted a common worldview (Koenig and Gogel, 1981), the basis for elite consensus and for concerted political agency (see Bond and Harrigan, this volume).

The findings of power structure researchers also challenged the managerialist position that saw a separation of ownership and control in the evolution of the modern corporation. As ownership became dispersed among many small shareholders, control of the firm was claimed to pass into the hands of disinterested managers (Berle and Means, 1932). If this were so, corporate directors and interlocks would be no more than window-dressing, irrelevant to economic power (Koenig et al., 1979). Power structure researchers questioned managerialism on many counts. On the level of corporations, Zeitlin (1974) analyzed the structure of ownership relations to show that, in the majority of cases, personal shareholding has been replaced by bank and insurance company shareholding, catapulting the latter, not managers, into controlling positions. On the individual level, Pfeffer (1987) 
argued that managers' goals are tied to their organizations' goals, especially in the case of corporations where top executives directly benefit from the firm's profitability through the shares they hold.

Studies such as these affirmed, in opposition to pluralism and managerialism, that corporations cannot be considered in isolation. They are embedded in a wider system of power through interlocking directorates and other relations. These multilevel relations shape corporate decisions and policies. The accomplishment of power structure research was to move beyond the "aggregative" methods of classic elite analysis, of pluralist political science, and of managerialism alike. These prenetwork approaches studied attributes of units of analysis (individuals or corporations), tacitly assuming the autonomy of the units, but did not systematically examine the structure of relations among them. In contrast, network analysis highlights the relations between units and the ways in which units (whether directors or corporations) are themselves shaped by their positions in systems of interrelations (Berkowitz, 1980).

By 1978, the research literature had burgeoned to the point that Fennema and Schijf, in their authoritative review, could offer a summary statement on the architecture and span of interlock networks in the developed capitalist societies:

In all cases financial institutions, banks and insurance companies have central positions in the network of interlocking directorates. Another very general result is that in all studies so far almost all the companies are directly or indirectly connected with each other (p. 327).

\section{Debates within the study of interlocks}

As network analysis of interlocks developed roots in the 1970s, internal debates grew within the field. Scott (1985) classifies approaches to the study of interlocks along two dimensions: first, an agentsystem axis, and second, an organization-individual axis. The intersection of these two axes define four approaches (see Table 13.1). 
Table 1. Approaches to the study of interlocks

\begin{tabular}{lcc}
\hline & Agent & System \\
\hline Individuals & Social background & Class cohesion \\
Corporations & Organizational & Intercorporate \\
\hline
\end{tabular}

Source: Scott (1985: 3).

The agent-centered approaches correspond for the most part to the prenetwork perspectives reviewed above. Focusing on organizational agents, interlocks become a characteristic of the firm that can be statistically related to performance or profitability. This not only diverts the agenda from questions of power; it fails to see that the goals and decision making of one firm are affected by the other firms with which it has relations of interdependency (Pfeffer, 1987). Focusing on individual agents, interlocks become properties of individuals, to be related to other personal characteristics, like wealth, education, class background and club membership (see Domhoff, 1967, 1974; Whitley, 1974). In reducing the social relations among directors to mere attributes, information on the actual system of interrelations that socially constitute the elite is sacrificed (Scott, 1985: 4).

The main debates that took place in the 1980s were situated at the structural, systemic level, between interorganizational approaches and a "class hegemony" approach that emphasized the integrative function of interlocks for leading members of a dominant class. The former developed along two lines. In viewing corporations as formal organizations and corporate networks as interorganizational fields (Breiger, 1974; Palmer, 1987), some researchers introduced ideas from the sociology of formal organization, as in Allen's (1974) claim that interlocks issue from attempts by organizations to reduce environmental uncertainties by co-opting elites from other organizations and as in Pfeffer's (1987) view that policies and decisions are designed to manage this uncertainty as organizations interlock to secure access to necessary resources from other organizations (cf. Pennings, 1980). Although this analytic lens afforded some insights on how organizational imperatives figure in intercorporate networks, in assimilating the corporation to the broader category of formal organization, 
its specificity as a key institution of advanced capitalism was lost. Issues of class, power, and capital accumulation have not been taken up by interorganizational researchers, even though these are arguably central to this field of study. (For a review of research on interorganizational networks, see Krackhardt, this volume.)

Other researchers took an intercorporate view. In this perspective, interlocks are instrumental means in the accumulation and control of capital. Earlier researchers, often affiliated with old left parties, had taken up this approach, basing their work on Hilferding's view of finance capital as an integration of the financial and industrial forms of capital, placing big banks in central positions within a power structure segmented into "financial groups" of aligned corporations (Aaronovitch, 1961; Menshikov, 1969; Park and Park, 1973 [1962]; Perlo, 1957; Rochester, 1936). Mintz and Schwartz (1985) employed this approach in their study of the power structure of American business in the 1960s. Observing that "large investments create a common fate; both lender and borrower depend heavily upon successful use of capital," (1985: 183) they analyzed how, by controlling flows of capital, banks shape industrial structure, directing capital toward the most profitable or promising lines of investment. In this system of financial hegemony, the largest banks are "vehicles for the class control of the economy" (1985: 254), and their central position in the interlock network reflects their hegemonic role as mediators of intraclass competition and meeting points for finance capitalists. In this formulation, bank-centered interlocks provide the information necessary, at the organizational level, to implement financial hegemony — the broad scan across sectors of the business community. But at the individual level the same interlocks help constitute an elite of finance capitalists: "a cohesive group of multiple directors tied together by shared background, friendship networks and economic interests, who sit on bank boards as representatives of capital in general" (1985: 254).

Finally, the class hegemony perspective saw corporations as "units in a class controlled apparatus of appropriation" (Soref and Zeitlin, 1987: 58). In this view, decision making takes place 
within a wider network, not of organizations but of individual members of the dominant class, whose particular interests are crystallized not in individual corporations but in control groups (families or financial cliques), and whose general class interests are reinforced by the manifold weak ties of interlocking outside directors. The analysis focuses on individual directors as members of the upper class, on the internal class structure, including the relations between the industrial and financial fractions of the capitalist class, and on how firms are connected through individual board members or corporate and family ownership. Interlocks are considered an expression of class cohesion, allowing for the integration of potentially contradictory interests (financial, industrial, commercial) of the richest families, whose investments span different sectors (Soref and Zeitlin, 1987: 60). In the class hegemony perspective, interlocks serve as channels of communication between individual directors, facilitating a common worldview among them (Koenig and Gogel, 1981), and giving the "inner circle" of interlockers access to a broad resource base from which to exert their hegemony in and beyond business circles (Useem, 1978).

Thus, system-centered approaches broke from the limitations of agent-centered and “aggregative" approaches to corporate elites and intercorporate networks (Berkowitz, 1980). Taking into account the embedded character of corporations and directors, these approaches depicted the power structure as a formation within which elite individuals and capitalist enterprises pursued particular goals while often contributing to wider class-based interests, as in the allocation of investment capital and the solidification of class hegemony. Many authors have stressed the complementarity between these approaches (Koenig and Gogel, 1981; Scott, 1985; Stokman et al., 1988). In combination, they depict corporate interlocks as "traces of power" (Helmers et al., 1975, cited in Fennema and Schijf, 1978) of two sorts: the instrumental power associated with the accumulation of capital and the expressive power associated with class hegemony (Carroll, 2004; Sonquist and Koenig, 1975). This raises a key question, succinctly posed by Mark Mizruchi: what do interlocks do? 


\section{What do interlocks do?}

In an extensive review of research literature, Mizruchi (1996) considered the causes and consequences of corporate interlocks. Focussing on the local rather than systemic significance of such ties, he noted both corporate and individual-level factors. For instance, interlocks can be created as mechanisms of co-optation or monitoring, as when a bank sends one of its officers to the board of one of its clients. Firms may invite prestigious directors on their boards to enhance their own reputations and contacts. Simultaneously, interlocks result from individual decisions to serve on multiple boards, which can be influenced by the prestige brought by the position, the remuneration, and the possibilities of making useful personal contacts (Mizruchi, 1996: 277). Any one explanation accounts for only a subset of all interlocks (Mizruchi, 1996: 274); hence, the precise significance of a given interlock is highly contextdependent.

In this regard, Scott's (1991: 184) observation that "power in intercorporate networks is based on at least three distinct kinds of intercorporate relation: personal, capital and commercial" has purchase. Commercial relations are simply trading links between buyers and sellers, but personal and capital relations are the main control relations surrounding corporations. Personal relations include interlocking directorships as well as kinship and friendship ties. Capital relations "are the links between business agents that result from shareholdings and from the granting and witholding of credit” (p. 184). While interlock networks open a window onto the social organization of corporate business, they comprise only one type of relation in a multilayered formation. Of particular significance in decoding interlocks as "traces of power" is the tendency, highlighted in the concept of finance capital, for interlocking directorships to be undergirded by capital relations (Scott, 2003: 159), including, in different contexts, intercorporate ownership, family control of multiple firms, institutional shareholding, and the credit relations through which banks exercise allocative power vis-à-vis 
borrowers.

\section{Comparative perspectives and the global interlock network}

By the 1980s, a vast body of empirical research, much of it centered on the United States, had yielded many detailed insights on the structure of intercorporate networks and corporate elites. What was lacking, however, was a comparative-historical perspective that could broaden and deepen knowledge beyond the tacit positing of the United States as the norm. It was in this context that John Scott (1985) produced the second edition of his Corporations, Classes and Capitalism, a compendium of research emphasizing the distinct routes that the advanced capitalist countries had taken to the corporate regimes of the late twentieth century, and the implications of those differences for network structure. In the same year, an international research group comparing the structure of intercorporate networks in 10 countries (the United States plus nine European states), published Networks of Corporate Power (Stokman et al., 1985). Although structural analysis of corporate interlocks had, since Jeidels, been pursued in various countries and had been advanced significantly by Dutch researchers (see Fennema and Schijf, 1978), these works began to broaden the focus of interlock research and at the same time to afford systematic cross-national comparison.

Drawing on such exemplars as Hilferding's analysis of bank control in Germany and Mintz and Schwartz's study of financial hegemony in the American corporate network, Scott $(1985,1987)$ noted that the capital relations that undergird interlock networks entail two forms of power: strategic control over specific corporations by means of concentrated blocs of shares and allocative power over capital flows, exercised by financial institutions. Distinct patterns of economic development and corporate law had produced variant configurations of these forms of economic power within national business systems and networks (cf. Whitley, 1999). In Germany, these forms intersected in the big "universal" banks, engendering a network of "oligarchic bank hegemony" in which banks were dominant in both 
capital allocation and control. In the postwar Japanese system, strategic and allocative power were also combined in discrete, bank-centered enterprise groups whose members held large blocs of shares in each other. In France, Belgium, and Italy, a "Latin model," organized around the extensive shareholdings of rival holding companies, imparted "a granular, group structuring of the economy" and of the network (Scott, 1985: 136). In the Anglo-American system of "polyarchic financial hegemony," which took shape in the aftermath of the Great Depression and was consolidated during the post-World War II boom, large financial institutions held powerful allocative positions opposite industrial firms while institutional investors such as pension funds held blocs of shares that enabled them to function collectively as "constellations of interests," exercising a constraining strategic power upon corporate management. The "polyarchic" character of the Anglo-American system made for an interlock network centralized around major banks and insurance companies, with little to no fractioning of the network into discrete financial groups (Scott, 1985: 129-260). With continuing growth in all advanced capitalist countries of depersonalized, institutional investment, Scott saw "a common move towards bank hegemony of a loosely structured kind" (p. 227).

A stream of comparative research flowed in the wake of these initiatives, and by the time Scott (1997) issued a completely rewritten compendium he was able not only to refine his earlier categories of variant patterns but to add the "post-Communist pattern" of collusive business organization in Eastern Europe and the "Chinese pattern" of corporate cooperation based on fraternal inheritance. More recent comparative studies include Maclean et al.'s (2006) investigation of business elites and corporate governance in France and the United Kingdom, which contrasted the thinness of the British network with the extensive involvement of wealthy families and the state in corporate France. Drawing on Bourdieusian field analysis, these authors explored "the social reality of how power is applied, channelled and contained in both countries" (2006: 164). Although in both cases serving on the boards of charitable institutions, business associations, public bodies, and the like was a mainstream medium 
for elite networking, the French elite favoured service on business associations while the British elite was heavily involved in arts, sport, and private clubs. Maclean et al. argued that "there are powerful, logical economic reasons why individuals rich in contacts are appointed as directors, leading to the self-perpetuating cohesion of the business elite on both sides of the Channel" (2006: 191). Paul Windolf's (2002) study of interlock networks in Europe and the United States also merits attention, not only for its further details on the organization of big business in advanced capitalism but for its attention to post-socialist networks in Eastern Europe. Windolf's analysis of the economic annexation of the former German Democratic Republic by the West German capitalist class — a process that produced an East German network of companies "legally and economically dependent upon western interests" (2002: 163) — raised the larger question of how, in a globalizing world, corporate power is configured on world capitalism's semi-periphery.

In one reply, Ilya Okhmatovskiy's (2005) study of the Russian interlock network evidenced an instructive reversal of the dominant pattern of financial hegemony found in core countries. In the aftermath of the 1998 financial crisis, Russian banks, previous leaders in converting public assets into capital were unable to access foreign capital or even to aggregate the savings of wary householders. They yielded their centrality to giant industrial firms whose resource exports generated deep pools of capital, on which the banks themselves came to depend. The study supported the concept of finance capital as an integration of financial and industrial forms, but showed how, when financial institutions are weak, a few industrial concerns can act as the coordinating centres of financial-industrial groups (2005: 452). Yun Tae Kim (2007), focusing on the level of individual Korean directors, detailed the role of exogamous marriage networks, common educational backgrounds, and exclusive social clubs in knitting together the major chaebol into a cohesive corporate elite with a wide range of connections with state officials, politicians, and the military elite. Although Kim found very little direct involvement of the corporate elite in political parties or the state, a plethora of informal connections 
"have provided chaebols not only with communication channels, but also with significant power and influence over policy-making” (2007: 34).

If studies such as these suggest that on the semi-periphery the move to impersonal possession and polyarchic financial hegemony is less advanced, other political-economic transformations, beginning in the 1980s, brought changes to the dominant pattern of business organization in core countries. The long-term tendency for capital to internationalize in the form of transnational corporations and financial markets, and the associated accumulation crisis of nationally organized capitalism, furnished favourable terrain for neoliberal policies of deregulation, pursued in the context of the increasingly visible impact of globalization on the structure, and functioning of corporate power. Scott (1997: 252) suggested that, with neoliberal globalization, the disarticulation of national core economies brought a disarticulation to national interlock networks. A study of change in the Canadian network from 1976 to 1996 did find an overall weakening of ties but also a tendency for Canada-based transnationals, both industrial and financial, to become more central in the network. The network became sparser mainly due to corporate governance reforms within the business community, implemented after 1995, which sought both to bolster shareholder rights and to prevent further corporate scandals, under the pressure of intensified international competition (Carroll, 2002a: 367).

Indeed, in the wake of deregulatory policies that rendered corporate business prone to Enronstyle scandals and corporate capitalism more susceptible to financial crisis, a governance reform movement was spearheaded by institutional investors in the 1990s and embraced by the Organization for Economic Cooperation and Development in 1998. The thrust of these reforms was to make corporate boards more effective and reliable in generating value for shareholders, the most powerful of whom, within systems of polyarchic financial hegemony, are institutional investors. These objectives dictated a normative ideal for corporate boards: that they be independent from top management, uninfluenced by interests other than shareholders, small enough to function efficiently, and composed 
of high-performance, well-oriented directors who are directly engaged in the decision-making process (Carroll, 2004: 34; Maclean et al., 2006: 213). Governance reforms reshaped the structure of corporate elites. They encouraged corporations, in the name of efficiency, to reduce the size of boards and to limit the number of directorships that members should hold concurrently; they weakened the basis for interlocks between non-shareholding creditors (typically banks) and debtors; they brought merit-based recruitment practices, opening boardrooms to more women and ethnic minorities (Carroll, 2004). The result, in countries where reforms were vigorously undertaken (but much less so in France [Maclean et al., 2006: 257] and elsewhere), was a thinning of the interlock network (as leaner boards were populated with fewer "big linkers"), a weakening of bank centrality, a modest shift away from patriarchal and toward multicultural board composition, and a decline of the "old boys networks" that had formed the dense core of corporate elites (cf. Carroll, 2004; Davis and Mizruchi, 1999; Heemskerk, 2007; Zweigenhaft and Domhoff, 1998).

Meanwhile, with the ongoing globalization of corporations, network analysis of corporate organization also went global. Key issues informing this strand of analysis have been (1) whether transnational interlocks between firms based in different countries are on the rise while national interlocks contained within countries are declining and (2) the spatial distribution of transnational interlocking. These questions, the second of which we take up later, are crucial to an understanding of the global intercorporate network and the global corporate elite.

Fennema (1982) made the earliest attempt to analyze a transnational intercorporate network. Mapping the network before and after the generalized international recession of 1973-74, he documented the consolidation of a Euro-North American component but found very few ties extending beyond that heartland of postwar capitalism. Fennema and Schijf’s (1985) more extensive network analysis, conducted as part of the 10 countries study (Stokman et al., 1985), clarified that the 1976 Euro-USA network linked the two continents only sparsely, largely through Britain, but that certain 
pairs of European countries (particularly Germany/Netherlands and Belgium/France) were quite profusely connected.

After a lapse of 17 years, Carroll and Fennema (2002) picked up the thread, with an analysis of Fennema's (1982) 1976 network and comparable data for 1996. They reported only a modest increase in transnational interlocking alongside the persistence of national networks, suggesting strong path dependencies reproducing the patterns of national corporate-elite organization discerned by Scott (1997). Kentor and Jang (2004) purported to show a much more dramatic increase in transnational interlocking between 1983 and 1998; however, questions were raised about the validity of their data (Carroll and Fennema, 2004). Whatever the case, research on the 500 leading corporations in the world in the most recent decade (1996-2006) finds a proliferation of transnational interlockers and a decline in national networkers, particularly in Japan, whose complement of leading corporations plummeted during the 1990s. The transnationalists have profuse ties to each other as well as to various national segments; thus, "in the inner circle of the global corporate elite, transnationalists and national networkers intermingle extensively, 'national' and 'supranational' spaces intersect, and whatever common interest takes shape is likely to blend "national" and "transnational" concerns" (Carroll, 2009: 308).

\section{Key Issues}

Across the last several decades, researchers have used an eclectic combination of techniques to map corporate networks at different scales and over various time frames. In this section we consider how four analytic issues have been addressed — the duality of corporate networks, questions of temporality, questions of spatiality, and the relation between interlocking directorates and capital relations.

The duality of interlock networks 
As we saw above, interlock networks can be fruitfully analyzed as interpersonal networks of directors forming a corporate elite or as intercorporate configurations. Although both approaches shed light on issues of social organization, each reveals only one facet of an inherently dualistic structure (Breiger, 1974), reducible neither to an elite of directors nor to a network of faceless corporations (Carroll, 1984: 249). The challenge has been to devise ways of representing interlock networks as configurations of both individual directors and the corporations they direct.

One approach has been to examine the network in two parallel analyses, as an interpersonal network of directors, linked to each other by virtue of their common corporate affiliations, and as an intercorporate network of interlocking directorates. Applying this strategy to the U.S. network, Bearden and Mintz (1987: 204) discovered "parallels in structure between the corporate and director networks", with regional organization, the merger of institutional and class interests, and the unifying role of big linkers occurring on both levels, and with bank boards serving as key sites in both the director network and the corporate network. Davis and colleagues (2003) also pursued parallel analyses in their smallworld study of change in the U.S. corporate network between 1982 and 1999. Although the mean degree of contacts decreased in both the interpersonal and intercorporate networks, at both levels the structure remained a small world, due to the integrative impact of both linchpin boards and linchpin directors: nodes whose ties across clusters create shortcuts that shrink the social space of the network. The remarkable consistency in connectivity, despite decreasing board interlocks, led these researchers to conclude that the small world of the corporate elite may issue less from elite institutions such as private schools and commercial banks and more from simple tendencies for boards to recruit wellconnected directors and for directors to prefer well-connected boards (p. 322).

Alternatively, the two levels can be considered in a single analysis of the interpersonal network by assigning to directors, as contextual variables, the attributes of the firms with which they are principally affiliated. Applying this approach to the Canadian network, Carroll (1984) found that 
industrial and financial firms controlled in Canada were strongly over-represented at the centre of the director network and in its principal cliques. The cliques were substantially organized around intercorporate ownership relations, supporting the conclusion that the Canadian corporate power structure revolves around "groups of interlocked capitalists who own and manage supra-corporate blocs of finance capital" (p. 265).

Researchers have also addressed the issue of duality directly by analyzing corporate affiliations as two-mode networks, thereby keeping both levels in view. Levine and Roy (1979) pioneered this approach with their "rubber-band" model, simultaneously clustering directors, and corporations on either side of a set of elastic board affiliations. This approach is limited to relatively small corporate networks, but it can be very revealing when applied to specific corporate empires, as in Carroll and Lewis's (1991) case study of the Brascan enterprise group, which in 1986 included 56 directors of two or more of the 14 major Canadian corporations controlled by or affiliated with the investment company Brascan Limited.

More recently, Alexander explored the boardroom networks of Australian directors, in an intricate two-mode analysis at 1976 and 1996. Following Faust and Wasserman (1993), Alexander (2003: 235) notes that both the interpersonal and intercorporate network have as their common infrastructure "the specific subset of memberships of all the interlockers/networkers in the affiliation network," which provides the resources for network connectivity. The patterning of such memberships simultaneously shapes both levels of the network. For instance, if directors tend to clump together on the same boards, as in a configuration built around corporate groups, the network will contain extensive redundancy, with the same directors linking the same boards in a system of "tight" interlocks that will dampen the spread of contacts in the interpersonal network. In the Australian case, although the density of intercorporate relations increased only slightly from 1976 to 1996, redundancy in the infrastructure decreased substantially, creating more networking resources, which increased the interpersonal 
network's density and drew many more boards into the dominant component.

\section{Temporality and Network Dynamics}

Intercorporate networks and corporate elites arise and persist in the broad sweep of history, and researchers have explored the temporality of these formations using a variety of models and designs. The most basic longitudinal research design depicts network structure at two moments, and interprets patterns of continuity and change in view of social and historical processes that are known to have occurred in the interim, as in Allen's (1974) comparison of the U.S. intercorporate network at 1935 and 1970. A slightly more elaborate longitudinal design incorporates three or more points of observation. Bunting and Barbour (1971) analyzed interlocking directorates among 207 American firms at six points from 1896 to 1964 and reported a decline in both inter-sectoral and intra-sectoral density after 1905, which they attributed to the introduction of anti-trust legislation. As well, Stanworth and Giddens (1975), in their study of the British network at seven points between 1906 and 1970, find that the concentration of firms has increased, along with the number of ties among firms; they also note that the top 50 British firms grew closer to the City banks since the beginning of the twentieth century. Gilles Piédalue (1976) replicated the snowball-sampling approach of Jeidels (1905) in a study of Canadian corporations from 1900 to 1930 that included four observation points. Like Jeidels, Piédalue began with the big banks and included corporations sharing directors with a bank or firms interlocked with a bank. He was able to show a dramatic expansion of the network, particularly in the first decade, and an increasing degree of interlocking. Mark Mizruchi’s (1982) follow-up to Bunting and Barbour examined the U.S. network at seven points from 1904 to 1974, revealing one large cluster of firms dominated by JP Morgan \& Co., which divided after 1919 into bank-centred cliques, with most corporations inhabiting the borders of multiple cliques. More recently, Barnes and Ritter (2001) tracked the thickening and then thinning of the American corporate network at four points from 1962 to 1995, and 
Barnes (2005), using the same data but examining the interpersonal network, explored the multiple dimensions of the American corporate elite's small world. By assessing how much the addition of extra-corporate affiliations decreased mean geodesic distances among directors, Barnes documented the decline of cultural ties (e.g., to museum and symphony boards) but a steady increase in the integrative role of elite affiliations with policy planning organizations. In line with Useem (1984), these trends depict a corporate elite becoming less concerned with maintaining social or civic ties and much more politically mobilized (cf. Carroll, 2004; Murray, 2006).

Although successive cross-sections allow researchers to pinpoint when major structural changes occur, they do not afford much basis for discerning the dynamics of change. With panel designs it is possible to analyze changes in both the composition of the set of largest corporations and the structure of relations among them. Carroll's (1986) analysis of turnover in the corporate constituents of the Canadian network and the links between them (1946-76) isolated as the stable core the set of multipledirector interlocks that were maintained throughout the three decades among firms that consistently ranked in the Top 100, despite changes in board composition. It was around this stable core that the major structural transformations occurred, as differential rates of accumulation and corporate reorganizations led firms to enter or exit from the Top 100 and as interlocks emerged or disappeared with corporate realignments. Panel design has also been used in assessing the stability of network parameters, as in Mariolis and Jones's (1982) study of relative centrality in the American corporate network, which was found to be extremely stable over the years 1962, 1964 and 1966, consistent with interpretations of interlocks as indicators of power, interdependence, and communication.

Following from the groundbreaking work of Helmers et al. (1975, cited in Fennema and Schijf, 1978: 324-25), which showed that in the Netherlands in the 1960s interlocks between financial institutions and industrial corporations had a high probability of being restored after retirement, resignation, or death of a director, several studies then employed restoration of broken ties as an 
indicator of the importance of an interlock to the two linked firms. Ornstein (1984) found that of the 5,354 interlocks among large corporations in Canada broken at some point during the first three postwar decades, 30 percent were restored, but the rate of restoration varied according to several factors. Interlocks carried by executives in one of the interlocked firms, and interlocks that were part of a multiple-interlock relation or a relation of intercorporate ownership between firms, were substantially more likely to be restored. Also, ties among companies controlled domestically were far more likely to be restored than were ties between Canadian- and American-controlled firms. And, after controlling for country of control, industry, and location of head office, financial-industrial interlocks were more likely to be restored than other ties. Richardson (1987) used cross-lagged correlations to show that in the Canadian network the profitability of industrial firms in 1963 predicted the restoration of their interlocks with financial institutions five years later, in a "circular and self-sustaining process" that reinforced companies' original profit position, supporting the theory of finance capital as capital integration.

Palmer's studies of broken ties in the American network found a low rate of restoration, particularly for non-executive interlocks. He concluded that although some interlocks facilitate formal intercorporate coordination, many of them are expressions of class hegemony, as interactions among leading directors and executives create "a loose, but nonetheless very real system of coordination in which firms are instruments of inner circle policy" (p. 70). Stearns and Mizruchi (1986), however, in a panel study that tracked 22 major industrial corporations over three decades, found evidence of "functional reconstitution," in which an industrial firm's broken tie to a financial institution is restored by an interlock to a different financial institution. This suggests that the incidence of purposive, strategic interlocking is higher than that estimated by the "direct" restoration of broken ties. In a complementary investigation using the same database, an event-history analysis of the creation of new interlocks showed that although firms with decreasing solvency and profitability were likely to appoint 
executives in financial institutions to their boards, all corporations were more likely to make such appointments during upswings in the business cycle, as capital needs expand. Both the specific situation facing a firm and the general context for capital accumulation appear to influence the creation of a financial-industrial interlock (Mizruchi and Stearns, 1988).

Although the bulk of sociological research on corporate networks has been set within the power-structure tradition, some of the most innovative analyses of temporality have explored practices only indirectly related to this central problematic. Galaskiewicz and Wasserman (1981), in a study of a regional corporate network, used Markov chains to model network processes. Focusing on the probability of establishing a linkage and the probability of an asymmetric (executive) linkage becoming reciprocated (or vice versa), they found that norms of reciprocity are not operative in corporate interlock networks, as they are in other interorganizational relations — consistent with the idea that interlocks carried by corporate insiders tend to be relations of influence and power. Diffusion of innovation analysis has also been employed in tracking network effects on speed of adaptation and patterns of prevalence of corporate governance practices. Here, Davis and Greve's (1997) study of the adoption of poison pills and golden parachutes in the American network (1980-86), marking a shift to "investor capitalism," is iconic. They showed how, amid the takeover waves of the 1980s, poison pills spread rapidly through board-to-board diffusion processes "in which firms adopted to the extent that their contacts had done so," but parachutes spread slowly, on the basis of geographical proximity rather than interlocking directorates (p. 29).

More recently, the development of actor-oriented modeling by Tom Snijders and his colleagues (Snijders, this volume; Steglich et al., 2006) has opened new possibilities for systematic analysis of network dynamics. As applied to intercorporate networks, this approach accounts for the changing pattern of inter-firm relations by estimating the underlying rational choices of network actors. For instance, van de Bunt and Groenewegen's (2007) study of collaborative agreements among genomic 
companies found that firms prefer to start partnerships with high-status (well-connected) companies and with companies that are already members of the same (2-clique) groups as the focal firm. The modeling procedure enabled these researchers to show that an apparent transitivity effect (whereby firms prefer to partner with companies that are already partners of partners) could be accounted for by the preference for high-status partners. Although actor-oriented modeling has only recently been applied to interorganizational relations, it offers intriguing opportunities to explore how macroconfigurations of corporate power are shaped by local, context-dependent decisions of corporations.

The career trajectories of directors and executives present yet another dynamic in the life of corporate networks. In their study of pathways to corporate management in the United States, Useem and Karabel (1986) found that although there are a variety of routes to the top, individuals who become members of the elite's inner circle are those with the greatest amount of both "scholastic" (elite education) and "social" (upper-class background) capital. The core of the elite, the segment most engaged in classwide leadership, appears to be recruited through mechanisms emphasized in Bourdieu's (1984) generalized theory of capital. In a fully longitudinal study of Dutch corporations over two decades (1960-80), Stokman et al. (1988) tracked the careers of the 105 big linkers whose extensive corporate directorships carried most of the network. The typical career pattern involved entering the network as an executive, acquiring several outside directorships, retiring from the executive position but maintaining (some of) the outside directorships, and finally exiting from the network altogether. As corporate boards recruit outside directors from a pool of executives of other large firms, and as executives move through this career sequence, the network is reproduced in its duality, partly on the basis of "permanent economic and financial relations between companies," and partly through recruitment processes that cause "global stability of the structure of the network, together with local instability of dyadic relations" (p. 203).

Finally, more qualitative approaches have highlighted the contingent, historical, and contextual 
character of network temporality. Davita Glasberg's (1987) case studies of the assertion of financial hegemony in restructuring insolvent corporations through such mechanisms as stock dumping are of great relevance to the current conjuncture of global capitalist crisis. Equally apposite is Brayshay and colleagues' (2006) qualitative study of “power geometries” in the rescue of Hudson's Bay Company (HBC) by the Bank of England during the last worldwide Depression. Eschewing a large-sample approach, these researchers began from the biography of a single person, Patrick Ashley Cooper, appointed governor of the HBC in 1931 and a director of the Bank of England in 1932, and thereupon assembled a remarkable set of international business contacts. By tracing Cooper's network in depth, through archival documents including his detailed personal diaries and letters, as well as Bank of England archives, Brayshay et al. constructed a rich longitudinal account of the corporate network and wide range of business- and policy-related practices that were enabled by it. Significantly, Cooper's embeddedness extended well beyond the boardrooms of London. Indeed, among his core group of special confidants were many people who had no overlapping corporate affiliations with him. The authors' sensible conclusion, that "a full reconstruction of an economic actor's array of contacts requires research beyond the stylized mapping of corporate networks" (p. 996), should serve as a challenge to researchers: they should delve into the kind of qualitative depth that can yield insight on specific mechanisms of social power, corporate control, and capital accumulation.

\section{Spatiality}

The question of how business networks are configured in space has preoccupied researchers since the consolidation of power structure analysis in the 1970s. The outstanding study from that era is Sonquist and Koenig's (1975) clique analysis of the American network circa 1969. Geocoding each corporation by the city of its headquarters, they found a structure of 32 overlapping cliques and their satellites, most of which were based in particular cities, with New York hosting the largest and most central group. 
Mintz and Schwartz (1981: 863) soon demonstrated the special position of New York as "the base of a national network of corporate interlocks, uniting regional clusters into a loosely integrated whole." Green's (Green, 1983; Green and Sempel, 1981) subsequent studies of the inter-urban network of corporate interlocks and of institutional stock ownership (Green, 1993) revealed a regionalized network dominated by the cities in which major financial institutions have their headquarters: New York and four secondary urban centres (Chicago, Boston, Los Angeles, and San Francisco). Later, Kono and his colleagues (1998) explored the possibility that local and nonlocal interlocking may have different determinants by examining the relationship between spatial propinquity of corporate headquarters and corporate interlocking among 500 U.S. firms in 1964. Interestingly, firms based in cities with exclusive upper-class clubs were more likely to interlock with each other, suggesting that "the local capitalist class social organization made possible by the colocation of corporate headquarters and upper-class clubs may be an instrument by which corporate elites manage their organizational environments, gaining information, trusted contacts, and access to national networks of elites" (Kono et al., 1998: 904). Of course, the regionally dispersed pattern of interlocking in the United States should not be abstractly generalized to other social formations. For instance, in Canada the corporate elite has long been centered in two cities — Montreal and Toronto — with the corporate network aligned along a highly integrated Toronto-Montreal axis (Clement, 1975). However, a study of the shifting corporate geography from 1946 to 1996 found that the westward flow of capital brought a plethora of corporate head offices to Calgary and Vancouver, creating a westward drift in the network itself. Still, the continuing preeminence of Toronto and Montreal as centers of finance produced a national network carried substantially by finance capitalists directing eastern-based financials and western-based industrials (Carroll, 2002b; see also, in the British case, Scott and Griff, 1984).

Recently, the geography of corporate networks has been explored at a global level. In a study of the global corporate elite (1996-2006) mentioned earlier, Carroll found a highly regionalized network, 
most of whose members are entirely embedded in national networks, with transnational interlocking mainly integrating corporate Europe or linking across to North America. Moreover, the growing cohesiveness of corporate Europe and the thinning of the American network shifted the global network's center of gravity, registering the success, from a business standpoint, of European integration, along with the decline of American hegemony (Carroll, 2009).

Several investigations have reached similar conclusions by charting the network of global cities on the basis of intercorporate relations. Using interlock data from 1996, aggregated by city of head office, Carroll (2007) found an interurban network in which Paris, London, and New York are particularly central, along with other cities of northeast North America and northwest Europe — the heartland of an Atlantic ruling class, in van der Pijl's (1984) terminology. Alderson and Beckfield's (2004) research on intercorporate ownership relations radiating from the world's 500 largest corporations provided a different vantage point on the world city system. Based on parent-subsidiary ownership relations, Tokyo emerged as the most central point. A follow-up investigation, analyzing change in the centrality of cities between 1980 and 2000, found a substantial reshuffling of the hierarchy and an increasing interurban disparity in centrality. Overall, the parent-subsidiary network of global cities appeared to be reproducing the "old" geography of centre-periphery relations in the worldsystem "in an even more pronounced form" (Alderson and Beckfield, 2007: 34). A finding common to all these studies has been the marginal position of corporations headquartered on global capitalism's semi-periphery. The global corporate elite, the global intercorporate network, and the world city network compose a core-periphery structure in which the global North continues to dominate (see also Kick et al., this volume).

\section{Capital Relations and Corporate Interlocks}

Although this chapter has focused on interlocking directorates, earlier we noted Scott's (2003: 159) 
thesis that interlocking directorships must be viewed "alongside the capital relations that undergird them." This point, central to an understanding of interlock networks, has been made by numerous researchers in various ways. Ratcliff's (1980) study of 78 commercial banks based in St. Louis evidenced a strong relationship between a bank's centrality in the interlock network and its loans to capitalists. Invoking Hilferding, Ratcliff concluded that the personal union of banking and corporate interests at the center of the capitalist class "is associated with a major flow of loan capital from banks to corporations and other related borrowers" (p. 565).

Although firm-by-firm data on bank loans are not generally available, data on intercorporate ownership have been widely employed in studies of corporate networks. An especially fruitful approach combines ownership and directorship data in the study of enterprises: sets of firms operating under common control, detectable in the coincidence of intercorporate ownership with shared directors. Applying this to the Canadian economy (1972-87), Berkowitz and Fitzgerald (1995) found a five-fold consolidation of enterprises, from 1,456 to 298, representing an enormous centralization of the control of capital, even though the actual number of legally defined large companies hardly changed at all. Windolf's $(2002: 42,69)$ comparative investigations of American and European corporate networks included ownership ties, and revealed sharp differences, into the 1990s, between continental regimes such as Germany's, where ownership and interlocking often coincide, and the British and American networks, which show few instances of significant intercorporate ownership and little overlap between the networks. Scott's (1986) comparative study of corporate shareholding and financial power in the United Kingdom, United States, and Japan showed that in the mid-1970s most large corporations were not controlled by single interests but were "tied through interweaving share participations into a system of impersonal possession" (p. 200). However, the precise shape of these systems varied between the Anglo-American pattern of financial hegemony and the Japanese structure of aligned participation in corporate sets (on the latter, see Scott 1997: 181-95). In the case of Australia, Murray’s $(2006,2008)$ 
research, considering both interlocking directorates and shareholding in top companies, reached the conclusion that "of themselves interlocks do not reveal the underlying power structures of companies" (Murray, 2008: 17). Indeed, in 2007 six top financial institutions operating in Australia (including Morgan Chase, HSBC, and Citicorp) held 34.1 percent of the market capitalization of the top 300 companies, indicating both an enormous centralization of financial power and a remarkable penetration by transnational capital.

Other research has looked purely at the network of intercorporate ownership ties. The German case was examined in a study by Kogut and Walker (2001) whose longitudinal design (running from 1993 to 1997) enabled a tracking of 101 acquisitions involving the top 550 German companies. Results showed a strong small-world effect, connecting firms through owners and owners through firms (2001: 325 ) and tendencies for acquisitions to make the network more centralized and for leading financial institutions to act as "brokering owners" in mergers and acquisitions. Grbic (2007) mapped the Japanese bank ownership network from 1988 to 1999, a period of massive restructuring and economic recession, which saw the collapse of major financial institutions. Defining as an ownership tie a block of 2.5 to 5 percent of a bank's share capital (the latter being the legal limit), Grbic compiled the twomode matrix of relations between Japanese banks and their institutional stockholders (including other banks), and then converted it to a one-mode matrix of institutional shareholders, linked by the number of banks in which they jointly held stakes. He found that nearly all the 80-odd institutional investors formed a single component, whose density approached 0.2 in every year; that the network structure fit a core-periphery pattern, with negligible factionalization; and that core actors were almost entirely financial institutions. Bearing in mind the longstanding division of corporate Japan into corporate sets, Grbic discerned a "dual network ... of crosscutting ties linking all banks and insurance firms while underneath exists a system organized by business groups that constitute separate spheres of influence" (p. 486). Studies such as these show how national intercorporate networks continue to be underpinned 
to some extent by capital relations entailing combinations of allocative power and strategic control, as theorized by Scott (1997).

\section{Conclusion}

Interlock research has come a long way since Jeidels's groundbreaking research. In the study of economic elites and the structure of corporate power, a variety of approaches has been used. We noted the limitations of focusing only on individual or corporate characteristics, in comparison to systemic approaches that consider the structure of the entire field. Among systemic approaches, we emphasized how the class hegemony and intercorporate perspectives complement each other. The former focuses on the individual directors who, as an organized minority, exercise classwide leadership and control the corporate structure as an "apparatus of appropriation". The latter views interlocks as vectors of interfirm communication, coordination, influence, and control. Insofar as intercorporate ties entail capital relations, two forms of power have been discerned: strategic control over corporations through ownership of blocs of shares, and control over capital flow exerted by financial corporations. Since the 1980s, interlock research has been enriched through comparative research designs and has started to look beyond national networks to the global level. Questions of network dynamics have been addressed through longitudinal designs and the study of broken and reconstituted ties. The geography of intercorporate networks has also been charted in the various core countries of capitalism and on a global scale.

If in the past few decades the methods of analysis have grown in sophistication, corporate elites and intercorporate networks have hardly remained static in their organizational features. The research literature reviewed above records major structural changes, often catalyzed by economic crises that provoke massive capital reorganizations and, sometimes, new regulatory frameworks. This dynamic of economic crisis and network re-composition, of course, has great relevance to the contemporary scene. 
The financial meltdown and global recession that took hold in the autumn of 2008 has already transformed the corporate landscape, claiming most of the major U.S. investment banks, for instance. With the collapse of the paper economy, and with widespread calls for re-regulation of corporate capital, the stage seemed set for a resurgent hegemony of whichever amalgamated financial institutions emerge from the crisis, under conditions of renewed state regulation and, in some countries, direct state control. Meanwhile, the growth of giant corporations on the semi-periphery presents another possible source of re-composition in the structure of corporate power. For corporate elites and intercorporate networks, both national and global, what is certain is that change is here to stay.

\section{References}

Aaronovitch, Sam (1961) The Ruling Class: A Study of British Finance Capital. London: Lawrence and Wishart.

Alderson, Arthur S., and Beckfield, Jason. (2004) "Power and position in the world city system," The American Journal of Sociology 109(4): 811-51.

Alderson, Arthur S., and Beckfield, Jason. (2007) "Globalization and the world city system: Preliminary results from a longitudinal data set," in P.J. Taylor, B. Derudder, P. Saey, and F. Witlox (eds), Cities in Globalization: Practices, Policies, Theories. London: Routledge. 21-36. Alexander, Malcolm. (2003) "Boardroom networks among Australian company directors, 1976 and 1996," Journal of Sociology 39(3): 231-51.

Allen, M.P. (1974) “The structure of interorganizational elite cooptation: Interlocking corporate directorates," American Sociological Review 39(3): 393-406.

Barnes, Roy C. (2005) “The multiple dimensions of the corporate elite's "small world” from 1962 to 1995," paper presented at the annual meeting of the American Sociological Association, Philadelphia, August 13-16. 
Barnes, Roy C., and Ritter, Emily R. (2001) “Networks of corporate interlocking: 1962-1995,” Critical Sociology 27(2): 192-220.

Bearden, James, and Mintz, Beth. (1987) "The structure of class cohesion: The corporate network and its dual," in M.S. Mizruchi and M. Schwartz (Eds.), Intercorporate Relations: The Structural Analysis of Business. Cambridge: Cambridge University Press. 187-207.

Berkowitz, Stephen D. (1980) "Structural and non-structural models of elites: A critique," Canadian Journal of Sociology 5(1): 13-30.

Berkowitz, Stephen D., and Fitzgerald, William. (1995) “Corporate control and enterprise structure in the Canadian economy: 1972-1987," Social Networks 17(2): 111-27.

Berle, Adolf A., and Means, Gardiner C. (1932) The Modern Corporation and Private Property. New York: Harcourt, Brace \& World.

Bourdieu, Pierre. (1984) Distinction: A Social Critique of the Judgement of Taste, Translated by R. Nice. Cambridge, MA: Harvard University Press.

Brayshay, Mark, Cleary, Mark, and Selwood, John. (2006) "Power geometries: Social networks and the 1930s multinational corporate elite," Geoforum 37(6): 986-98.

Breiger, Ronald L. (1974) “The duality of persons and groups," Social Forces 53(2): 181-90.

Brownlee, Jamie. (2005) Ruling Canada: Corporate Cohesion and Democracy. Halifax: Fernwood Publishing.

Bunting, David, and Barbour, Jeffrey. (1971) "Interlocking directorates in large American corporations, 1986-1964," Business History Review 45(3): 317-35.

Carroll, William K. (1984) “The individual, class, and corporate power in Canada," Canadian Journal of Sociology 9(3): 245-68.

Carroll, William K. (1986) Corporate Power and Canadian Capitalism. Vancouver: University of British Columbia Press. 
Carroll, William K. (2002a) “Does disorganized capitalism disorganize corporate networks?” Canadian Journal of Sociology 27(3): 339-71.

Carroll, William K. (2002b) "Westward ho? The shifting geography of corporate power in Canada," Journal of Canadian Studies 36(4): 118-42.

Carroll, William K. (2004) Corporate Power in a Globalizing World: A Study in Elite Social Organization. Oxford: Oxford University Press.

Carroll, William K. (2007) "Global cities in the global corporate network," Environment and Planning A 39(10): 2297-323.

Carroll, William K. (2009) “Transnationalists and national networkers in the global corporate elite," Global Networks 9(3): 289-314.

Carroll, William K., and Fennema, Meindert. (2002) "Is there a transnational business community?" International Sociology 17(3): 393-419.

Carroll, William K., and Fennema, Meindert. (2004) "Problems in the study of the transnational business community: A reply to Kentor and Jang," International Sociology 19(3): 369-78.

Carroll, William K., and Lewis, Scott. (1991) "Restructuring finance capital: Changes in the Canadian corporate network, 1976-1986," Sociology 25(3): 491-510.

Clement, Wallace. (1975) The Canadian Corporate Elite: An Analysis of Economic Power. Toronto: McClelland and Stewart.

Davis, Gerald F., and Greve, Henrich R. (1997) “Corporate elite networks and governance changes in the 1980s," The American Journal of Sociology 103(1): 1-37.

Davis, Gerald F., and Mizruchi, Mark S. (1999) “The money center cannot hold: Commercial banks in the U.S. system of corporate governance," Administrative Science Quarterly 44(2): 215-39.

Davis, Gerald F., Yoo, Mina, and Baker, Wayne E. (2003) "The small world of the American corporate elite, 1982-2001," Strategic Organization 1(3): 301-26. 
Domhoff, G. William. (1967) Who Rules America? Englewood Cliffs, NJ: Prentice-Hall.

Domhoff, G. William. (1974) The Bohemian Grove and Other Retreats: A Study in Ruling-Class Cohesiveness. New York: Harper \& Row.

Domhoff, G. William (Ed.). (1980) Power Structure Research. Beverly Hills, CA: Sage.

Faust, Katherine, and Wasserman, Stanley. (1993) "Correlation and association models for studying measurements on ordinal relations," Sociological Methodology 23: 177-215.

Fennema, Meindert. (1982) International Networks of Banks and Industry. The Hague: M. Nijhoff.

Fennema, Meindert, and Schijf, Huibert. (1978) “Analysing interlocking directorates: Theory and methods," Social Networks 1(4): 297-332.

Fennema, Meindert, and Schijf, Huibert. (1985) "The transnational network," in F. N. Stokman, R. Ziegler and J. Scott (eds), Networks of Corporate Power: A Comparative Analysis of Ten Countries. Cambridge: Polity Press. 250-66.

Galaskiewicz, Joseph, and Wasserman, Stanley. (1981) “A dynamic study of change in a regional corporate network," American Sociological Review 46(4): 475-84.

Glasberg, Davita. (1987) "The ties that bind? Case studies in the significance of corporate board interlocks with financial institutions," Sociological Perspectives 30(1): 19-48.

Grbic, Douglas (2007) “The source, structure, and stability of control over Japan's financial sector," Social Science Research 36(2): 469-90.

Green, Milford B. (1983) "The interurban corporate interlocking directorate network of Canada and the United States: A spatial perspective," Urban Geography 4(4): 338-54.

Green, Milford B. (1993) “A geography of institutional stock ownership in the United States,” Annals of the Association of American Geographers 83(1): 66-89.

Green, Milford B., and Semple, R. Keith. (1981) “The corporate interlocking directorate as an urban spatial information network," Urban Geography 2(2): 148-60. 
Heemskerk, Eelke M. (2007) Decline of the Corporate Community: Network Dynamics of the Dutch Business Elite. Amsterdam: Amsterdam University Press.

Helmers, Hendrika M., Mokken, Robert J., Plijter, Rene C., and Stokman, Frans N.. (1975) Graven naar Macht. Op zoek naar de kern van de Nederlandse ekonomie. Amsterdam: Van Gennep.

Hilferding, Rudolf. (1981 [1910]) Finance Capital: A Study of the Latest Phase of Capitalist Development, Translated by M. Watnick and S. Gordon. London: Routledge \& K. Paul. Jeidels, Otto. (1905) “Das Verhältnis der deutschen Grossbanken zur Industrie mit besonder Berücksichtigung der Eisenindustrie (Relation of the German big banks to industry with special reference to the iron industry)," Staats- und sozialwissenschaftliche Forschungen 24(2): 1-271.

Kentor, Jeffrey, and Jang, Yong Suk. (2004) "Yes, there is a (growing) transnational business community: A study of global interlocking directorates, 1983-98," International Sociology 19(3): $355-68$.

Kim, Yun Tae. (2007) “Korean elites: Social networks and power,” Journal of Contemporary Asia 37(1): 19-37.

Koenig, Thomas, and Gogel, Robert. (1981) "Interlocking corporate directorships as a social network," American Journal of Economics and Sociology 40(1): 37-50.

Koenig, Thomas, Gogel, Robert, and Sonquist, John. (1979) "Models of the significance of interlocking corporate directorates," American Journal of Economics and Sociology 38(2): 173-86.

Kogut, Bruce, and Walker, Gordon. (2001) "The small world of Germany and the durability of national networks," American Sociological Review 66(3): 317-35.

Kono, Clifford, Palmer, Donald, Friedland, Roger, and Zafonte, Matthew. (1998) "Lost in space: The geography of corporate interlocking directorates," The American Journal of Sociology 103(4): $863-911$.

Levine, Joel H., and Roy, William S. (1979) "A study of interlocking directorates: Vital concepts of 
organization," in P.W. Holland and S. Leinhardt (Eds.), Perspectives on Social Network Research. New York: Academic Press. 349-78.

Maclean, Mairi, Harvey, Charles, and Press, Jon. (2006) Business Elites and Corporate Governance in France and the UK. Basingstoke, UK: Palgrave Macmillan.

Mariolis, Peter, and Jones, Maria H. (1982) “Centrality in corporate interlock networks: Reliability and stability," Administrative Science Quarterly 27(4): 571-85.

Menshikov, S. (1969) Millionaires and Managers: Structure of the U.S. Financial Oligarchy. Moscow: Progress Publishers.

Mills, C. Wright. (1956) The Power Elite. New York: Oxford University Press.

Mintz, Beth, and Schwartz, Michael. (1981) "Interlocking directorates and interest group formation," American Sociological Review 46: 851-69.

Mintz, Beth, and Schwartz, Michael. (1985) The Power Structure of American Business. Chicago: University of Chicago Press.

Mizruchi, Mark S. (1982) The American Corporate Network: 1904-1974. Beverly Hills: Sage.

Mizruchi, Mark S. (1996) "What do interlocks do? An analysis, critique, and assessment of research on interlocking directorates," Annual Review of Sociology 22: 271-98.

Mizruchi, Michael S., and Schwartz, Michael. (1987) “The structural analysis of business: An emerging field," in M.S. Mizruchi and M. Schwartz (Eds.), Intercorporate Relations: The Structural Analysis of Business. Cambridge: Cambridge University Press. 3-22.

Mizruchi, Mark S., and Stearns, Linda Brewster. (1988) “A longitudinal study of the formation of interlocking directorates," Administrative Science Quarterly 33(2): 194-210.

Moore, Gwen. (1979) “The structure of a national elite network," American Sociological Review 44(4): $673-92$.

Murray, Georgina. (2006) Capitalist Networks and Social Power in Australia and New Zealand. 
Aldershot, UK: Ashgate.

Murray, Georgina. (2008) “Invisible invaders: Does Australia have a transnational class?” paper presented at the ISA Forum of Sociology, Barcelona, September 4-8.

Okhmatovskiy, Ilya. (2005) "Sources of capital and structures of influence: Banks in the Russian corporate network", International Sociology 20(4): 427-57.

Ornstein, Michael D. (1984) "Interlocking directorates in Canada: Intercorporate or class alliance?" Administrative Science Quarterly 29(2): 210-31.

Palmer, Donald. (1987) “The dual nature of corporate interlocks," in M. Schwartz (Ed.), The Structure of Power in America: The Corporate Elite as a Ruling Class. New York: Holmes and Meier. 6074.

Park, Libbie, and Park, Frank. (1973 [1962]) Anatomy of Big Business. Toronto: James Lewis \& Samuel.

Pennings, Johannes M. (1980) Interlocking Directorates: Origins and Consequences of Connections Among Organizations'Boards of Directors. San Francisco: Jossey-Bass.

Perlo, Victor. (1957) The Empire of High Finance. New York: International Publishers.

Pfeffer, Jeffrey. (1987) “A resource dependence perspective on interorganizational relations,” in M. S. Mizruchi and M. Schwartz (Eds.), Intercorporate Relations: The Structural Analysis of Business. Cambridge: Cambridge University Press. 22-55.

Piédalue, Gilles. (1976) “Les groupes financiers au Canada 1900-1930_Étude préliminaire,” Revue d'histoire de l'Amérique française 30(1): 3-34.

Porter, John. (1955) “Elite groups: A scheme for the study of power in Canada," Canadian Journal of Economics and Political Science 21(4): 498-512.

Porter, John. (1956) “Concentration of economic power and the economic elite in Canada," The Canadian Journal of Economics and Political Science 22(2): 199-220. 
Porter, John. (1957) “The economic elite and the social structure in Canada," The Canadian Journal of Economics and Political Science 23(3): 376-94.

Ratcliff, R.E. (1980) "Banks and corporate lending: An analysis of the impact of the internal structure of the capitalist class on the lending behavior of banks," American Sociological Review 45(4): $553-70$.

Richardson, R. Jack. (1987) “Directorship interlocks and corporate profitability,” Administrative Science Quarterly 32(3): 367-86.

Rochester, Anna. (1936) Rulers of America: A Study of Finance Capital. London: Lawrence \& Wishart. Scott, John. (1985) “Theoretical framework and research design,” in F.N. Stokman, R. Ziegler, and J. Scott (Eds.), Networks of Corporate Power: A Comparative Analysis of Ten Countries. Cambridge: Polity Press. 1-19.

Scott, John. (1986) Capitalist Property and Financial Power. Brighton, Sussex: Wheatsheaf Books. Scott, John. (1987) "Intercorporate structures in Western Europe: A comparative historical analysis," in M.S. Mizruchi and M. Schwartz (eds), Intercorporate Relations: The Structural Analysis of Business. Cambridge: Cambridge University Press. 208-32.

Scott, John. (1991) "Networks of corporate power: A comparative assessment," Annual Review of Sociology 17: 181-203.

Scott, John. (1997) Corporate Business and Capitalist Class. New York: Oxford University Press. Scott, John. (2003) "Transformations in the British economic elite," Comparative Sociology 2(1): 15573.

Scott, John. (2008) "Modes of power and the re-conceptualization of elites," in M. Savage and K. Williams (eds), Remembering Elites. Oxford: Blackwell. 27-43.

Scott, John, and Griff, Catherine. (1984) Directors of Industry: The British Corporate Network, 19001976. Cambridge: Polity Press. 
Sonquist, John A., and Koenig, Thomas. (1975) “ Interlocking directorates in the top U.S. corporations: A graph theory approach," The Insurgent Sociologist 5(3): 196-230.

Soref, Michael, and Zeitlin, Maurice. (1987) "Finance capital and the internal structure of the capitalist class in the United States," in M.S. Mizruchi and M. Schwartz (Eds.), Intercorporate Relations: The Structural Analysis of Business. Cambridge: Cambridge University Press. 56-84.

Stanworth, Philip, and Giddens, Anthony. (1975) “The modern corporate economy: Interlocking directorships in Britain, 1906-1970," The Sociological Review 23(1): 5-28.

Stearns, Linda Brewster, and Mizruchi, Mark S. (1986) "Broken-tie reconstitution and the functions of interorganizational interlocks: A reexamination," Administrative Science Quarterly 31(4): 52238.

Steglich, Christian E.G., Snijders, Tom A.B., and West, Patrick. (2006) “Applying SIENA: An illustrative analysis of the coevolution of adolescents' friendship networks, taste in music, and alcohol consumption." Methodology 2: 48-56.

Stokman, Frans N., van der Knoop, Jelle, and Wasseur, Frans W. (1988) "Interlocks in the Netherlands: Stability and careers in the period 1960-1980," Social Networks 10: 183-208.

Stokman, Frans N., Ziegler, Rolf, and Scott, John (Eds.). (1985) Networks of Corporate Power: A Comparative Analysis of Ten Countries. Cambridge: Polity Press.

Sweezy, Paul M. (1953) The Present as History: Essays and Reviews on Capitalism and Socialism. New York: Monthly Review Press.

Useem, Michael. (1978) “The inner group of the American capitalist class,” Social Problems 25(3): $225-40$.

Useem, Michael. (1984) The Inner Circle: Large Corporations and the Rise of Business Political Activity in the U.S. and U.K. New York: Oxford University Press.

Useem, Michael, and Karabel, Jerome. (1986) "Pathways to top corporate management," American 
Sociological Review 51(2): 184-200.

van de Bunt, Gerhard G., and Groenewegen, Peter (2007) “An actor-oriented dynamic network approach: The case of interorganizational network evolution." Organizational Research Methods 10: 463-82.

van der Pijl, Kees. (1984) The Making of an Atlantic Ruling Class. London: Verso.

Whitley, Richard. (1974) "The city and industry: The directors of large companies, their characteristics and connections," in P. Stanworth and A. Giddens (eds), Elites and Power in British Society. London: Cambridge University Press. 66-82.

Whitley, Richard. (1999) Divergent Capitalisms. New York: Oxford University Press.

Windolf, Paul. (2002) Corporate Networks in Europe and the United States. New York: Oxford University Press.

Zeitlin, Maurice. (1974) "Corporate ownership and control: The large corporation and the capitalist class," American Journal of Sociology 79(4): 1073-119.

Zweigenhaft, Richard L., and Domhoff, G. William. (1998) Diversity in the Power Elite: Have Women and Minorities Reached the Top? New Haven, CT: Yale University Press. 